\title{
CHALLENGES AND OPPORTUNITIES IN THE NEW MILLENIUM: THE SERV!CE SECTOR BECKONS
}

\author{
Ankit Majmudar*
}

\begin{abstract}
The Article briefly summarises the development and impact of the services sector in the new economy, with specific reference to its scope and future in the Indian context.
\end{abstract}

The $20^{\text {th }}$ century saw mankind make extraordinary leaps in science and technology- man conquered the moon, several formerly fatal diseases became curable, and the internet was developed.

The creation of the internet in fact dominated the closing years of the $20^{\text {th }}$. century, as well as the beginning of the $21^{\text {st }}$ - both from a scientific as well as an economic perspective. The development of the "new economy" - a sector of industry where manufacturing capacities and economies of scale seemed to be rendered irrelevant, and the novelty of an idea determined its value - saw a sea change in the types of opportunities available in the new millenium. Although the internet "bubble" itself appears to have been rather shortlived, it has left in its wake far reaching changes in the way in which people do business. Even traditional manufacturing sectors have embraced technology and harnessed the power of the new economy to enable them to reduce their costs and increase their efficiencies.

* Ankit Majmudar is a corporate lawyer working in Mumbai at Wadia Gandhi \& Co., and can be contacted at ankitmaimudar@hotmail.com 


\section{Development of the Service Sector}

While the internet dominated the closing years of the last millenium, the last few decades of the $20^{\text {th }}$ century saw extraordinary growth in one particular sector that of services. The service sector today constitutes a substantial percentage of economic activity, and it would appear that, in future years, this percentage looks set to increase further. Even the Indian economy, which began, and to an extent still is, a predominantly agrarian economy, has metamorphosed into an industrial economy and has now mushroomed into a services economy.

The service sector is constituted of a variety of occupations, some of which are the world's oldest professions- legal services being an example and others of relatively recent origin, such as soffware services. In all, services include a number of industries, including management consultancy, advertising, banking services, investment advisory, and the list goes on. While there can be no uniform definition of the kinds of activities that fall within the spectrum of "services", the sector does have certain characteristics that are rather unique.

For example, the services sector is really composed of intangibles- there is no physical, tangible, product produced. Instead, the offerings of the service sector are linked with perceived value additions. For example, a management consultant is not productive in the traditional sense of the term. A management consultant would not constitute a profit centre of a company, as understood in the traditional sense. Yet the value addition that such a person may be able to provide to an organisation could be invaluable. Such a consultant may be able to suggest ways to improve efficiency in the organisation in a manner that benefits the organisation- services which may not have a tangible, measurable value, but which are still vital to ensure the successful functioning of an entity.

\section{India in the Services Sector}

India is well positioned to take advantage of the growth of the services sector. With its large population, to find adequate employment opportunities in agriculture and industry would be difficult. However, services offer scope to utilise the large work force available to us. India also offers several unique facets, the most important of which are inexpensive skilled labour, widespread familiarity with the English language, and a huge consumer market.

India's ability to grow in the services sector is evident in recent developments. Several large global accounting and management consultancy firms have set up their operations in India and are growing rapidly. Law firms are growing rapidly and the legal profession is no longer looked upon as the last resort of a 
student. Advertising agencies have grown rapidly in recent years, and of late, have seen global consolidation.

But India has truly demonstrated its potential for excellence in software. Today, India is a recognised software super power and companies like Infosys and Tata Consultancy Services have set up global operations to offer their services to customers around the world. Even though the internet boom has been shortlived, and the stock markets have failed to elevale tech stocks to the historic highs seen earlier, software services, as such, continue to grow at a rate well in excess of general industry growth.

Even from an educational viewpoint, several institutions in India are able to offer quality education in software - thus ensuring the presence of a skilled work force in the future in the software sector.

Another area that is likely to provide substantial growth in the near future is that of customer relationship management and business process outsourcing. This involves organisations that provide services of back office processing and call centres. With its low cost labour, India is positioned to provide these services at rates that are much lower than those available abroad. This has seen a mushrooming of call centres across India. Further, several venture capital and private equity funds have made substantial investments in ventures in this sector.

These sectors, therefore, provide tremendous opportunities to India to develop leadership positions internationally in these business areas, and provide competent assistance to foreigners who desire to avail of these services from Indian personnel.

The challenge, however, is to ensure that customer service provided by these organisations continues to match global standards. For this, every organisation must monitor compliance to quality standard carefully. In the services sector, since there is no tangible product, it would be the individuals rather than the products that would be subject to review for determining quality. Tremendous attention must therefore be paid to the performance of persons engaged in the services sector. In addition, the talent pool available to the services sector must continue, and the sector should not be put to a disadvantage by reason of a lack of adequately qualified or skilled personnel. Tremendous importance must, therefore, be provided to ensuring that adequate educational infrastructure is kept in place for procuring the growth of these areas.

\section{Conclusion}

As a developing country, India has certain peculiarities which have, in the past, 
affected its ability to match global developments. In the service sector, however, India appears to have found an opportunity to leap-frog over its contemporaries and match the developed world in every respect. For example, today India is already touted as the soffware factory to the world. Call centres and back office management seem to be another area in which India is likely to lead global developments.

Yet we also need to recognise that globalisation and liberalisation have changed the face of our economic existence. No longer is India in its own shell, isolated from the rest of the world. Today, our companies, and our people, have to compete at a global level and have to learn to survive this competition. Such survival would mean adopting global best practices at every possible circumstance. Nowhere is this more evident than in the service sector. In a sector enormously dependant upon individual contributors, every effort would have to be taken to ensure that we match global standards. For this purpose, we would have to ensure that personnel are provided with adequate trainingfor which we would require educational institutions of excellence. Further, Indian companies would have to be able to attract the best available talent, for which they would have to offer compensation structures, career opportunities and work quality. Only if these are ensured, would Indian companies be able to compete with their global contemporaries successfully. 